\title{
OBITUARY
}

\section{WILLIAM TREGARTHEN DOUGLASS}

IT is with deep regret that we chronicle the death of this very eminent engineer. Mr. Douglass, who was drowned through the upsetting of a small sailing yacht off Start Point in August last, was born on March 23rd, 1857, and was educated at Dulwich and King's College. His first work in connection with lighthouses, with which his name will always bs associated, was during the erection of the present Eddystone lighthouse when he acted as assistant engineer to his father. From that time onwards he was occupied in many engineering works of a permanent nature. He designed and constructed nearly forty lighthouses in different parts of the world, and carried out harbour works and sea defence works at numerous places in Scotland and around the English coast.

His interest in aeronautics was evidenced by his membership of the Aëronautical Society, while during the remodelling, in 1911, of the Society's constitution he rendered invariable assistance on the Committee which was chosen for that purpose.

To his fine talents and business capabilities was added a warm-hearted, even impulsive, nature, and his many friends in the engineering and aeronautical worlds will - unite in mourning both for a brilliant career so tragically cut short and for the charming, kindly and inspiring personality of the man we knew and admired.

The Council of the Aëronautical Society, at a meeting on August 13th, passed the following resolution :-

" The Council of the Aëronautical Society of Great Britain has heard with great regret of the death of its late distinguished member, William Tregarthen Douglass, who rendered invaluable assistance in 1911, at a critical period in the history of the Society, and desires to extend the deepest sympathy to his family in their sad bereavement."

\section{SAMUEL FRANKLIN CODY}

FEW indeed are the men whose loss could inflict so bitter a blow upon aeronautics as that of S. F. Cody, who summed up in his unique personality almost the entire history and development of aviation in this country. But the effect of his loss will be felt beyond the narrow confines of these shores, for his achievements were of international repute and aroused a world-wide echo.

On the morning of August 7th he fell with his passenger, Mr. W. H. B. Evans, from a height of some 200 feet with his biplane at South Farnborough. Both were killed on the spot. Subsequent inquiry points to the failure of the structure of his machine in the air. At that let the matter rest.

Samuel Franklin Cody was born in Texas in 1861. At an early age he came over to England with his wife and family and toured the country with a "Wild West" show. The living was a precarious one, though ever after Cody looked back with affectionate regret upon those early strenuous days of toil and failure, that left their ineradicable mark upon the man, moulding his boisterous and picturesque personality.

It would be useless to inquire the origin of his life-long interest in kites ; no doubt it was one of those freaks of nature that lead to epoch-making results, a trend of his subconscious mind. Suffice it to say that he resolved to exploit the kite as much for the purpose of his own advancement as for the ultimate future which he saw dimly looming ahead. He built a team of kites, attached them to a rowing-boat, and by their unaided means sought to cross the Channel. Nearly he succeeded, yet even his comparative failure proved the turning-point in his career, since it led to his discovery by Colonel Templer, then director of the Balloon Factory. Before long he was definitely appointed 